\title{
Will the ASEAN Intergovernmental Commission of Human Rights (AICHR) Grow Its Teeth?
}

\author{
Yessi Olivia \\ Department of International Relations University of Riau \\ Kampus Bina Widya Simpang Baru, Riau 28193 \\ Email: yessi_o@yahoo.com
}

\begin{abstract}
ASEAN Intergovernmental Commission on Human Rights (AICHR) was established in 2009. Its main functions are to promote and to protect human rights and fundamental freedoms of the people of ASEAN. Since the beginning of its formation, AICHR has been criticized for being a toothless institution. This is because of the weak nature and power given to this body. This paper analyzes what the future lies for AICHR. Will it continue to become a partial human rights mechanism or will it transform into an independent human rights body. It is argues that several factors will determine the future of AICHR. Firstly, is the ability of AICHR in internalizing human rights norms. Secondly, is the commitment of ASEAN countries to human rights promotion and protection. Thirdly, is the endless endeavor coming from civil society not only criticizing but also supporting AICHR. The structure of this paper is as follows. The first section elaborates theories on why states join or signing human rights regime or treaties. This will be followed by providing a brief profile of ASEAN and emphasizing on the organization norms. Next, the paper explains the anatomy of AICHR and provides brief comparison between AICHR and several regional human rights systems. The origin and the development of AICHR are discussed in the next section, followed by analyzing the future of AICHR.

Keywords: AICHR, human rights body, regional mechanisms, norms, regime
\end{abstract}

\begin{abstract}
Abstrak
Komisi Antarpemerintah ASEAN untuk Hak Asasi Manusia (AICHR) didirikan pada tahun 2009. Fungsi utamanya adalah untuk mempromosikan dan melindungi hak asasi manusia (HAM) dan kebebasan dasar masyarakat ASEAN. Sejak awal pembentukannya, AICHR telah dikritik karena lembaga kosong. Hal ini dikarenakan sifat lemah dan kekuasaan yang diberikan kepada badan ini. Tulisan ini menganalisis akan seperti apa masa depan AICHR. Apakah akan terus menjadi parsial mekanisme HAM atau akan berubah menjadi sebuah badan HAM independen. Tulisan ini berpendapat bahwa ada beberapa faktor yang akan menentukan masa depan AICHR. Pertama, kemampuan AICHR dalam internalisasi norma-norma HAM. Kedua, komitmen negara-negara ASEAN untuk mempromosikan HAM dan perlindungan. Ketiga, usaha maksimal dari masyarakat sipil yang tidak hanya mengkritik. tetapi juga mendukung AICHR. Struktur dari tulisan ini adalah, Pertama, menguraikan teori mengapa negara bergabung atau menandatangani rezim HAM atau perjanjian. Ini akan diikuti dengan memberikan profil singkat dari ASEAN dan menekankan pada norma-norma organisasi. Selanjutnya, makalah ini menjelaskan anatomi AICHR dan memberikan perbandingan singkat antara AICHR dan beberapa sistem regional HAM. Asal-usul dan perkembangan AICHR akan dibahas pada bagian berikutnya, diikuti dengan menganalisis masa depan AICHR.

Kata Kunci: AICHR, badan HAM, meknisme regional, norma, rezim
\end{abstract}

\section{INTRODUCTION}

The ASEAN Intergovernmental Commission of Human Rights (AICHR) is the a special body within ASEAN, which according to its Terms of References (ToR), its main objectives are "to promote and protect human rights and fundamental freedoms of the peoples of ASEAN." AICHR has spurred various reactions since it was launched in 2009. On one side ASEAN has been praised for taking the right move for creating a human rigths institution. It is said that the establishment of AICHR shows that ASEAN has 
taken the rhetoric into action "from being state-centric to more people-oriented [...] albeit at a very initial stage." 2 On the other side criticisms have been levelled at this ASEAN's human rights body. For example, AICHR is regarded as a tool for ASEAN countries to protect themselves from international enquiries of human rights abuses. ${ }^{3}$ Furthermore, the word 'toothless' has often brought up due to the limitation of the mandates that AICHR has. There is no clear mandate about human rights protection as AICHR is not entrusted with a power to give sanction or punishment for human rights violators. In addition, this body is not impartial because the ToR of AICHR specifically mentions that AICHR only serves as a consultative body to the governments of ASEAN countries.

This topic is interesting to be analyzed because when ASEAN was formed in 1967, human rights issues was something that is off the table. There was no discussion about human rights promotion and protection in all of ASEAN's official meetings. The norm of non interference written in the 1976's Treaty of Amity and Cooperation in Southeast Asia even affirms that ASEAN countries will not discussed their internal affairs openly. Questions then arose on when AICHR was set up by ASEAN. Why did ASEAN countries agree to form a human rights body? This is a region that consists of not only democratic countries but also authoritarian countries. Thus, interpretation about state's responsibilities to its people or the rights of people are inevitably varied. ASEAN countries are also known to have problems with past and present human rights violations. Thus, with the creation of AICHR, what is then the future of this human rights body? How is it going to tackle human rights issues in this region? Will it finally grow its teeth or will it continue to become a weak body and partial?

The paper tries to address these questions. It argues that the AICHR's future is depended on several factors, such as the success of internalisation of human rights norms among ASEAN countries. Next, the future of AICHR will also be influenced by the pressure coming from the civil society toward ASEAN countries leaders. And what is also important, the success or failure of the ASEAN Community will be a major factor in determining the future of AICHR.

The structure of this paper is as follows. The first section reviews theoretical findings regarding the emergence of human rights regime. This will be followed by describing AICHR and contrasting AICHR with other regional human rights systems in Europe and America. The evolution of ASEAN and the birth of AICHR will be explained in the third section, followed by an analysis on the future of AICHR especially on how AICHR could evolve.

\section{THEORETICAL APPROACHES}

In regard to states relations to human rights machinery, scholars have taken these following arguments as the foundation of their research. To begin with, it is important to note that committing to international or regional human rights mechanisms is not the same as involving in trade or security cooperation. When states sign trade treaties, the treaties will influence the trade relations among states parties to the agreements. States may adjust their trade policies to the international agreement to smoothen the bilateral relationship. Human rights treaties or protocols, however, do not have similar effect. When a states signs and ratifies certain human rights treaty, it will be responsible to up hold the content of the treaty within its jurisdiction. Simply put, human rights treaties only affect the relation between state and its people. Second, consigning to human rights regime or organization will result in the sovereignty costs that states must pay. ${ }^{4}$ This is because human rights regime will put states through monitoring or judiciary process as part of the human rights promotion and protection programs.

When state's decision is said to be based on cost benefit analysis, assenting to human rights treaty is something that should not be the option in the first place. First because monitoring process is can be seen as an act interference from outsider to state's domestic affairs. And second human treaty membership does not offer valuable benefit other than assurance from 
other states that its people will not be harmed. ${ }^{5}$ So, again, why do states go to the trouble of forming a supranational body on human rights? Among various research that have been conducted, the explanations of states commitment to human rights mechanisms can be grouped into two main theories. The first theory focuses more on coercion and inducement (rationalist) and the later emphasises on normative persuasion (ideational).

The rationalist explanations are mostly coming from the school of realism in International Relations. Realists based their assumptions on how the nature of the international system shapes a state's policy and how power is distributed among states. The establishment of international agreements like human rights treaties is then interpreted as a way for dominant states to pursue their interests. Thus, the membership of other states, especially the less dominant states, will be seen as a result of power politics enforced by the powerful hegemonic states. Andrew Moravscik points out that the more power capabilities that states have in coercing and inducing "recalcitrant states to accept, adjust to, and comply with international human rights norms", "the more likely is an international regime to form and prosper." ${ }^{6}$ Moreover, states who agree to join human rights body will get their geopolitical power, ideological ends enhanced and that they can avoid conflict or sanction with great powers. ${ }^{7}$

While rationalists talk about how powerful states dominate a regime and threaten or induce smaller states to join the regime, ideational theorists look at the factors of persuasion and socialization. In regard to persuasion, governments, according to Moravscik, "are swayed by the overpowering ideological and normative appeal of the values that underlie them" especially after the period of the Second World War. There is also the determination to uphold certain ideas, about what is right and what is wrong. For the ideationalist, these perceptions will lead states to form a formal institution where it can legitimize the ideas they believe in. ${ }^{8}$ In addition, the rise of human rights regimes are argued to be linked to the efforts of nongovernmental organizations (NGOs) and in spreading the discourse of human rights. Connections between local NGOs and international NGOs, which coined the term transnational advocacy networks, has resulted in the socialization of human rights not only among the society but also among leaders.

Besides these two main theories, there is another theoretical explanation which according to James Munro serves as "a kind of stepping stone" that links the notion of "states acting due to coercion by other states" and "states acting because they have been persuaded of the rectitude of protecting human rights." 9 This third explanation focuses on the acculturation process where there is a "pressure to assimilate" that can be imposed by actors from within and outside. ${ }^{10}$ The acculturation or "the general process of adopting the beliefs and behavioral patterns of the surrounding culture," involves of several mechanisms from cognitive and social pressures to norm conformity. ${ }^{11}$

\section{ASSOCIATION OF SOUTHEAST ASIAN NA- TIONS (ASEAN)}

The Association of Southeast Asian Nations (ASEAN) was formed in 8 August 1967. The creation of the regional organization was initiated by five countries: Indonesia, Malaysia, Singapore, Thailand, and the Philippines. These countries are also known as the founding fathers of ASEAN. Initially, the reason of establishing an organization in Southeast Asia region was to ease the political tension among these neighboring countries by focusing more on regional cooperation. The regional cooperation, especially in terms of economic development, has resulted in a tremendous success and even placed ASEAN to be the most significant hub of international cooperation. In its 46 years of existence, ASEAN is now consist of ten countries with the accession of Brunei Darussalam in 7 January 1984, followed by Vietnam in 28 July 1995, Lao DPR and Myanmar in 23 July 1997 and Cambodia in 30 April 1999.

It is important to know that ASEAN is known for its exceptional norms. Unlike other regional organizations that are homogenic in terms of political or 
cultural similarities, ASEAN comprises of states with different background from country sizes, colonial and post colonial experiences, government systems and ideologies. What has become the basic of its regionalism is the collection of norms that have been consistently practiced by its members. According to Amitav Acharya, ASEAN's norms "derive from the local, social and political milieu" that "have been enshrined in a variety of documents." 12 Acharya categorizes the norms into five categories: the non-use of force and the pacific settlement of disputes, regional autonomy and collective self-reliance, doctrine of non interference in the internal affairs of states, reject an ASEAN military pact and prefer for bilateral defence cooperation and the ASEAN Way. ${ }^{13}$

In regard to ASEAN Way, this concept has no fixed definition. It is vague and highly criticized for being just a rhetoric coming from ASEAN leaders. It is widely known that ASEAN leaders has been using the term to distinguish ASEAN from other organizations despite its lack of meaningful cooperation. To sum up, ASEAN Way embodies the act of politeness and non confrontational and preferring not to use formal mechanisms in its conflict resolution management. Problems related to the organization or involved several members of the organization are solved indirectly through musyawarah (consultation), mufakat (consensus). Furthermore, decision making process in ASEAN depends on "direct and indirect measures of restraint, pressure, diplomacy, communication and trade-offs" ${ }^{14}$ in contrast to other organizations where aggressive mechanism such as intervention is taken. However, despite its weaknesses, ASEAN Way could be the answer to ASEAN's endurance and existence after all these years since the members has been focusing on efforts to collaborate more closely and not spending too much time confronting problems. ${ }^{15}$

\section{ASEAN INTERGOVERNMENTAL COMMISSION ON HUMAN RIGHTS (AICHR)}

The creation of AICHR is part of the mandate written in the ASEAN Charter under the Article 14. According to its ToR, the purposes of of AICHR are as follows:

1. To promote and protect human rights and fundamental freedoms of the peoples' of ASEAN

2. To uphold the rights of the peoples of ASEAN to live in peace, dignity and prosperity

3. To contribute to the realisation of the purposes of ASEAN as set out in the ASEAN Charter in order to promote stability and harmony in the region, friendship and cooperation among ASEAN Member States, as well as the well-being, livelihood, welfare and participation of ASEAN peoples in the ASEAN in the ASEAN Community building process.

4. To promote human rights within the regional context, bearing in mind national and regional particularities and mutual respect for different historical, cultural and religious backgrounds, and taking into account the balance between rights and responsibilities.

5. To enhance regional cooperation with a view to complementing national and international efforts on the promotion and protection of human rights; and

6. To uphold international human rights standards as prescribed by the Universal Declaration of Human Rights, the Vienna Declaration and Programme of Action, and international human rights instruments to which ASEAN Member States are parties.

Moreover, AICHR's mandate among other are: developing strategies for promotion and protection and framework for human rights cooperation, and enhancing public awareness of human rights. AICHR is consist of ten commissioners where each commissioner represents one ASEAN country. These commissioners are appointed by the government and serve for three years.

Since it was launched in 2009, AICHR has been criticized for several reasons. Firstly, eventhough the purposes of AICHR emphasis on the promotion and protection of human rights and the commitment to endorse the international standards of human rights, the works of AICHR is limited due to ASEAN's 
intention to secure the ASEAN norms as highlighted in the Purposes Article. There are the respect of "noninterference in the internal affairs of ASEAN Member states," ${ }^{16}$ and "respect for the right of every Member State to lead its national existence free from external interference, subversion and coercion. ${ }^{17}$ And there is the norm of "pursuance of a constructive and nonconfrontational approach and cooperation to enhance promotion and protection of human rights." 18

Second, critiques have been pointing out the weak nature of AICHR. The word 'intergovernmental' in AICHR and its function as a consultative body to the governments underline the relationship between AICHR and ASEAN members. The condition where AICHR is depended on ASEAN countries, as argued by critiques, might impact the independency of AICHR because it only serves the need of ASEAN governments. Third, while the ToR states that AICHR is created to promote and protect human rights in Southeast Asia, there is no concise explanation on how it will protect human rights in ASEAN not to mention that AICHR does not have a power to give sanction to human rights abusers. The closest things to protection that AICHR could provide are mentioned in the Article 4:

8. To engage in dialoge and consultation with other ASEAN bodies and entities associated with ASEAN, including civil society organizations and other stakeholders, as provided for in Chapter V of the ASEAN Charter.

9. To consult, as may be appropriate, with other national, regional and international institutions and entities concerned with the promotion and protection of human rights.

10. To obtain information from ASEAN Member States on the promotion and protection of human rights.

Based on those clauses above, it can be seen that AICHR is given very limited power in the protection of human rights. NGOs, as AICHR's stakeholders, had tried to engage with AICHR in solving human rights violation, however AICHR "declined to accept these complaints, viewing them as beyond its powers." 19

Since it was formed, most of AICHR programs has been focusing on promotion of human rights, such as presenting and discussing human rights obligations and commitment to ASEAN countries, disseminating/training on human rights and ASEAN Human Rights Declarations to government officials and students, and workshop on women's human rights. As part of its capacity building programs, AICHR has also organized training for trainers to enhance their skills and knowledge in human rights advocacies. ${ }^{20}$

Moreover, in contrast to AICHR which lacks of supporting instruments and documents, regional human rights systems in America and Europe are independent and well equipped. Council of Europe, for example, has two main bodies in promoting and protecting human rights which are Commissioner for Human Rights and the European Court of Human Rights consecutively. The Commissioner for Human Rights is given the mandate "to promote the awareness of and respect for human rights in 47 Council of Europe member states" as stated in Resolution (99) 50 on the Council of Europe Commissioner for Human Rights. ${ }^{21}$ While the Commissioner is responsible in promoting human rights, the European Court of Human Rights, which was built in 1959, is accountable in taking the case submitted by individual or State on the matter of "violations of the civil and political rights set out in the European Convention on Human Rights." 22 The number of judges serve in the Court is 47, representing the number of states parties to the European Convention on Human Rights. Despite the judges' election process begins with state's proposing a number of judges, judges of the Court do not represent their states. They are "independent and cannot engage in any activity that would be incompatible with their duty of independence and impartiality." ${ }^{23}$

Besides Council of Europe, Organization of American States (OAS) also has two main human rights bodies; Inter-American Commission on Human Rights (IACHR) and Inter-American Court of Human 
Rights. According to the Charter of the OAS, the principal function of the IACHR "shall be to promote the observance and protection of human rights and to serve as a consultative organ of the Organization in these matters." ${ }^{24}$ IACHR based its work on three pillars: the individual petition system, monitoring of the human rights situation in the Member States, and the attention devoted to priority thematic areas.

Several rapporteurs and unit are assigned to take care the thematic areas that include: indigenous people rights, women's rights, freedom of expression, unit on LGBT rights, and economic, social and cultural rights.

The Inter-American Court of Human Rights, which was established in 1979, is responsible to enforce and interpret the provision of the American Convention on Human Rights and providing adjudicatory and advisory duties. Based on the Statute of the InterAmerican Court of Human Rights, the Court consists of seven judges with six years of serving term. They are elected based on their capacities and competencies in human rights. In this Court, individuals can not take the case directly to the Court and that the Court is only served as the last resort. ${ }^{25}$

\section{WHY DID ASEAN ESTABLISH AICHR?}

When ASEAN was first created, human rights was not part of the concerning issue to this organization. In the context of rivalry between two superpowers in the region added by the rising disputes among Southeast Asia countries, creating an organization that could managed the political tension was the top priority.

The effort did work as ASEAN survived the Cold War and boosted the economic cooperation among its members. After the Cold War ended, however, ASEAN faced with new challenges that brought significant impact to the foundation of the organization. One of the challenges is human rights.

In 1993 the international community gathered in Austria to attend the World Conference on Human Rights. The main purpose of the Conference was to produce "a common plan for strengthening of human rights work around the world." ${ }^{26}$ ASEAN leaders showed their reluctance to the idea of giving power to
United Nations human rights bodies ${ }^{27}$, and on the idea of human rights' universality. ${ }^{28}$ The unwillingness was even demonstrated in the regional meeting before the World Conference was taken place. In the 'Bangkok Declaration', Asian countries, including ASEAN members, stated that while they are "welcoming the increased attention being paid to human rights in the international community" and reaffirming the commitments to "principles contained in the Charter of the United Nations and the Universal Declaration on Human Rights," they decline the universality of human rights by emphasizing that human rights "must be considered in the context of a dynamic and evolving process of international norm-setting, bearing in mind the significance of national and regional particularities and various historical, cultural and religious backgrounds." ${ }^{29}$ Surprisingly, eventhough ASEAN showed doubt to the universality of human rights norms, in July 1993 ASEAN decided to assent to the Vienna Declaration and Programme of Action and agreed to establish a regional human rights mechanism.

Nevertheless, it took ASEAN more than a decade to take the next step in establishing its human rights mechanisms. In 2004 ASEAN members signed the Vientiane Action Programme (VAP), a plan to further its regional integration. Under the VAP, ASEAN gave its assurance that it will form human right system for the region. Eventually, the clear path of forming such organization came when ASEAN Charter was adopted by ASEAN countries in 2008. According to the Article 14 of the ASEAN Charter, it is stated that:

1. In conformity with the purposes and principles of the ASEAN Charter relating to the promotion and protection of human rights and fundamental freedoms, ASEAN shall establish an ASEAN human rights body.

2. This ASEAN human rights body shall operate in accordance with the terms of reference to be determined by the ASEAN Foreign Ministers Meeting. 
One year following the adoption of the ASEAN Charter, ASEAN introduced the ToR of AICHR and AICHR was formally established.

Why did ASEAN finally embrace human rights norm and form AICHR? Three theories elaborated in the previous section can be applied here. In regard to rationalist theory, the decision to finally setting up a human rights body is argued to be the result of pressures coming from outside of the region. Stephen McCarthy, for example, brings the case of how Burma's admission to ASEAN has put ASEAN under international criticisms for not able to stop the military junta from violating human rights. This condition is believed to be damaging ASEAN's credibility. McCarthy argues that the Burma factor has forced ASEAN to restore its reliability by "discussing liberal ideas like democracy and human rights" ${ }^{30}$ In addition, the decision to have AICHR is a rational choice because ASEAN succeeded in toning down the critics coming from outside and inside ASEAN by creating a human rights body eventhough the system "lacks the power to challenge deep-seated norms which the Association wishes to preserve (sovereignty, non intervention)." ${ }^{31}$

Next, concerning with the ideational theory, the establishment of AICHR cannot be separated from the rise of civil society in the ASEAN countries (albeit varies in each country) since the 1990s. In regard to ASEAN and human rights, numerous efforts have been taken by NGOs to give pressure to ASEAN leaders to create regional human rights machinery. Most notable groups are: ASEAN People's Assembly (a network of NGOs), Annual Conference of Civil Society (a conglomeration of civil society actors), Asian Forum for Human Rights and Development (FORUM-ASIA), Working Group for an ASEAN Human Rights Mechanism and Solidarity for Asian Peoples' Advocacies (SAPA). The last two groups are related to ASEAN works on human rights. ${ }^{32}$ In 2007, four national human rights commissions from Indonesia, Malaysia, Thailand and the Phillippines even signed a Declaration of Cooperation which includes "to advice their respective governments on the steps that can be taken in establishing an ASEAN human rights mechanism." ${ }^{33}$

Lastly, the acculturation theory can explain how ASEAN leaders will finally accepted AICHR. Munro point out the 'evolutionary approach' mentioned in the ToR and how the body will "develop and mature over time." 34 The 'evolutionary approach', according to Munro, reflects the 'norm localization' where "states integrate a foreign norm into their existing culture and norm hierarchy." ${ }^{35}$ In the end, after the human rights norms internalized, significant changes might occur, such as establishing a regional human rights court.

\section{THE FUTURE OF AICHR}

In the previous section, this paper has demonstrated the explanations on why ASEAN countries has changed its view regarding human rights body. As the countdown clock reminds us that the beginning of ASEAN Community in 2015 is approaching, what the future lies for AICHR? This paper argues that the future of AICHR, whether it will grow its teeth or not, depends on several following factors. First is the success of AICHR in internalizing the human rights norm as stated in the Article regarding its mandate and function. Since its formation in 2009, AICHR has not yet prove itself to be the leading human rights defender in the region. For example, AICHR has been turning a blind eye to human rights violations in the case of oppression of Rohingya people in Burma. Nonetheless, the limited power given to AICHR does not mean that AICHR cannot do anything for human rights protection. As suggested by Yuyun

Wahyuningrum, AICHR should:

"...be more creative in articulating and developing a number of mechanisms that need to be implemented in its Terms of Reference including a mechanism for providing advisory services and technical assistance (Article 4.7), on consultation with its stakeholders (Article 4.9), to obtain information from member states (Article 4.10), public information and communication (Article 6.9) and on the review (Article 9.6)." ${ }^{\prime 36}$ 
The stake of finding a creative way in endorsing mechanisms is high since AICHR has the potential to evolve as stated in the Article 2.5: "Adoption of an evolutionary approach that would contribute to the development of human rights norms and standards in ASEAN." It indicates that AICHR might transform into an independent human rights body in the future if AICHR succeed in promoting and protecting human rights to its stakeholders.

Furthermore, the future of AICHR also lies on its commitment to engage with its stakeholders as part of the institutional building endeavors. This is important because, as one of critics point out, while AICHR serves as one of the important instruments in the ASEAN integration, "AICHR has shown no willingness to engage with civil society organisations, and has not been eager to listen to the victims of human rights abuses." ${ }^{37}$ Engagement with stakeholders should be AICHR's top priority since AICHR needs the supports from them in order to reach its goal in promoting human rights. Wahyuningrum states that:

"AICHR should realize that their work will be meaningless and irrelevant without the supports and engagement of all sectors, including civil society organizations. Meaningful and constructive participation shall be considered as essential to the human rights framework that promotes good governance, democracy and peace in ASEAN." ${ }^{38}$

Second, changes in AICHR are depend on how receptive and commit ASEAN countries to its human rights body. Abhisit Vejjaviva, the former Prime Minister of Thailand, in his remarks on the inaugural ceremony of AICHR in 2009 admitted that AICHR's mandate and functions are far from perfect. However, he declared that the creation of AICHR "is not an end in itself but an evolutionary process towards strengthening the human rights architecture within the region." ${ }^{39}$ The Review Section in the ToR of AICHR specifically mentions that "ToR shall be initially reviewed five years after its entry into force." It means that there is a chance for ASEAN countries to make a correction to its human rights body albeit gradually. ASEAN countries should take the opportunity of reviewing ToR seriously if they want to improve the promotion and protection of human rights in Southeast Asia. This paper also argues that implementation of ASEAN Community in 2015 is also part of factors that will determine the future of AICHR. The success of ASEAN integration politically, economically and socially, will automatically strengthen ASEAN instruments all together.

The third factor that will impact the future of AICHR is the consistency of civil society to keep pressuring ASEAN to enhance the capacity and capability of AICHR. This include the demand to amend the ToR of AICHR, especially in its mandate and function, and to pay more attention to the protection of human rights. In addition to that, civil society should work hand in hand with AICHR in promoting and protecting human rights in the region through dialogue and capacity building programs.

\section{CONCLUSION}

This paper started with outlining several theoretical findings regarding the establishment of human rights mechanisms and why states joined a human rights regime or treaties. The discussion was then followed by describing the profile of ASEAN and emphasized on its exceptional norms. The next section explained how ASEAN norms play a major influence on the development of AICHR. By elaborating several weaknesses that AICHR, this paper discussed about the future of AICHR. To sum up, the future of AICHR, whether it could grow its teeth or not, lies on three factors. First is the ability of AICHR to socialize and internalize human rights norms, and engage with various stakeholders. Second is the commitment of ASEAN countries to human rights promotion and protection and third, the involvement of civil society in developing the capability of AICHR by demanding ASEAN countries to make better changes.

\section{ENDNOTES}

ASEAN, ASEAN Intergovernmental Commission on Human Rights (Terms of Reference) (Jakarta: ASEAN, 2009), 3.

2 Hao Duy Phan, "The ASEAN Inter-Governmental Commission on 
Human Rights and Beyond," Asia Pacific Bulletin 40 (2009)

3 The Jakarta Post, 22 July 2009.

4 Andrew Moravscik, "The Origins of Human Rights Regimes: Democratic Delegation in Postwar Europe," International Organization 54, no. 2 (2000): 219

5 Oona Hathaway, "The Cost of Commitment," John M. Olin Center for Studies in Law, Economics, and Public Policy Working Papers 273 (2003): 1-38

6 Moravcsik, 221

7 Hathaway, 1945

8 Laurence R. Helfer, "Overlegalizing Human Rights: International Relations Theory and the Commonwealth Caribbean Backlash Against Human Rights Regimes, " Columbian Law Review 102 (2002): 1845

9 James Munro, "The Relationship between the Origins and Regime Design of the ASEAN Intergovernmental Commission on Human Rights (AICHR)," The International Journal of Human Rights 15, no. 8 (2011): 1188

10 Ryan Goodman and Derek Jinks, "How to Influence States: Socialization and International Human Rights Law," Duke Law Journal 54 (2004): 12-13

11 ibid.

12 Amitav Acharya, Constructing a Security Community in Southeast Asia: ASEAN and the Problem of Regional Order (New York: Routledge, 2003), 63.

13 i bid.

14 Gillian Goh, "The 'ASEAN Way' Non-Intervention and ASEAN's Role in Conflict Management," Stanford Journal of East Asian Affairs 3, no. 1 (2003), 118. Also see L Leviter, "The Asean Charter: ASEAN Failure or Member Failure", International Law and Politics 43, iss. 159 (2010)

15 Mely Caballero-Anthony, Regional Security in Southeast Asia: Beyond the ASEAN Way, (Singapore: Institute of Southeast Asian Studies, 2005)

16 Article 2.1.b, ToR of AICHR,

17 Article 2.1.C, ToR of AICHR

18 Article 2.4, ToR of AICHR

19 Vitit Muntarbhorn, "Development of the ASEAN Human Rights Mechanisms," Directorate-General for External Policies of the Union, Briefing Paper (2012)

20 Archives of AlCHR activities can be retrieved in http://aichr.org/ category/activities/

21 Council of Europe, "Commissioner for Human Rights Mandate," Council of Europe, http://www.coe.int/t/commissioner/Activities/ mandate en.asp (Accessed 27 October 2013).

22 European Court of Human Rights, "The Court in Brief," European Court of Human Rights, http://www.echr.coe.int/Documents/ Court in brief ENG.pdf (Accessed 27 October 2013).

23 European Court of Human Rights, "The ECHR in 50 Questions," European Court of Human Rights, http://www.echr.coe.int/ Documents/50Questions_ENG.pdf (Accessed 27 October 2013).

24 Department of International Law OAS, "Charter of the Organization of American States," Department of International Law OAS, http://www.oas.org/dil/treaties_A-

41_Charter_of_the_Organization_of_American_States.htm\#ch15 (Accessed 27 October 2013).
25 Organization of American States, Petition of Case System: Informational Brochure, Organization of American States (2010)

26 Office of the High Commissioner for Human Rights, "World Conference on Human Rights," Office of the High Commissioner for Human Rights, http://www.ohchr.org/EN/ABOUTUS/Pages/ ViennaWC.aspx (Accessed 20 October 2013)

27 Stephen McCarthy, "Beyond Naypyidaw: Burma and the ASEAN Way to Human Rights," Regional Outlook Paper 20, (2009)

28 Yessi Olivia, The Development of Regional Human Rights Systems in America and Southeast Asia, Paper was presented in the American Studies Association Annual Meeting, 15-18 November 2012, San Juan, Puerto Rico, 8

29 United Nations, "Report of the Regional Meeting for Asia of the World Conference on Human Rights," United Nations, http:// www.unhchr.ch/Huridocda/Huridoca.nsf/TestFrame/ 9d23b88f115fb827802569030037ed44? Opendocument (Accessed 23 October 2013)

30 McCarthy, p.12

31 Catherine Rinshaw, "Understanding the New ASEAN Intergovernmental Commission on Human Rights: the Limits and Potential Theory", University of New South Wales Faculty of Law Research Series Working Paper 53, (2010): 15.

32 Muntarbhorn, p. 15

33 Working Group for an ASEAN Human Rights Mechanism, "ASEAN Four Signs Declaration of Cooperation," Working Group for an ASEAN Human Rights Mechanism, http://www.aseanhrmech.org/ news/asean-four-signs-declaration-of-cooperation.html (Accessed 27 October 2013).

34 Munro, p.1191

35 ibid.

36 The Jakarta Post, 18 March 2013

37 HRWG, "AICHR Review Offers Hope for Human Rights Progress", HRWG http://www.hrwg.org/publication/articles/item/162-aichrreview-offers-hope-for-human-rights-progress (Accessed 28 October 2013)

38 Diplomacy Training Program, "ASEAN CSOs call for AICHR to wider spaces for meaningful participation with civil society", Diplomacy Training Program, http://www.dtp.unsw.edu.au/documents/ DraftPressRelease_CSO_AICHR_Engagement-YYedit.pdf

39 ASEAN, "Remarks by H.E. Abhisit Vejjajiva, Prime Minister of the Kingdom of Thailand, on the Occasion of the Inaugural Ceremony of the ASEAN Intergovernmental Commission on Human Rights (AICHR), "ASEAN http://www.asean.org/news/item/remarks-by-heabhisit-vejjajiva-prime-minister-of-the-kingdom-of-thailand-on-theoccasion-of-the-inaugural-ceremony-of-the-asean intergovernmental-commission-on-human-rights-aichr (Accessed 28 October 2013)

\section{BIBLIOGRAPHY}

Acharya, Amitav. Constructing a Security Community in Southeast Asia: ASEAN and the Problem of Regional Order, New York: Routledge, 2003.

ASEAN. ASEAN Intergovernmental Commission on Human Rights (Terms of Reference) Jakarta: ASEAN, 2009.

Council of Europe, "Commissioner for Human Rights Mandate," Council of Europe, http://www.coe.int/t/commissioner/Activities/ 
mandate_en.asp (Accessed 27 October 2013)

Council of Europe, "The Council of Europe in Brief," Council of Europe, http://www.coe.int/aboutCoe/index.asp?page=nosObjectifs\&l=en (Accessed 27 October 2013)

Department of International Law OAS, "Charter of the Organization of American States," Department of International Law OAS, http:// www.oas.org/dil/treaties_A41 Charter_of_the_Organization_of_American_States.htm\#ch15 Diplomacy Training Program, "ASEAN CSÖs call for AICHR to wider spaces for meaningful participation with civil society," Diplomacy Training Program, http://www.dtp.unsw.edu.au/documents/ DraftPressRelease_CSO_AICHR_Engagement-YYedit.pdf

European Court of Human Rights, "The Court in Brief," European Court of Human Rights, http://www.echr.coe.int/Documents/ Court_in_brief_ENG.pdf (n.d) (Accessed 27 October 2013)

European Court of Human Rights, "The ECHR in 50 Questions," European Court of Human Rights, http://www.echr.coe.int/ Documents/50Questions_ENG.pdf (2012) (Accessed 27 October 2013)

Goodman, Ryan and Derek Jinks. "How to Influence States: Socialization and International Human Rights Law." Duke Law Journal 54 (2004): 7-55

Hathaway, Oona. "The Cost of Commitment." John M. Olin Center for Studies in Law, Economics, and Public Policy Working Papers 273 (2003): 1-38

Helfer, Laurence R. "Overlegalizing Human Rights: International Relations Theory and the Commonwealth Caribbean Backlash Against Human Rights Regimes." Columbian Law Review 102 (2002): 1834-1911

HRWG, "AICHR Review Offers Hope for Human Rights Progress", HRWG http://www.hrwg.org/publication/articles/item/162-aichrreview-offers-hope-for-human-rights-progress (Accessed 27 October 2013)

McCarthy, Stephen,"Beyond Naypyidaw: Burma and the ASEAN Way to Human Rights," Regional Outlook Paper 20, (2009): 1-18

Moravcsik, Andrew. "The Origins of Human Rights Regimes: Democratic Delegation in Postwar Europe." International Organization 54, no 2 (2000): 217-252

Munro, James. "The Relationship between the Origins and Regime Design of the ASEAN Intergovernmental Commission on Human Rights (AICHR)." The International Journal of Human Rights 15, no.8 (2011): 1185-1214

Office of the High Commissioner for Human Rights, "World Conference on Human Rights," Office of the High Commissioner for Human Rights, http://www.ohchr.org/EN/ABOUTUS/Pages/ ViennaWC.aspx

Organization of American States, Petition of Case System: Informational Brochure, Organization of American States (2010)

Organization of American States, What is IACHR, Organization of American States, http://www.oas.org/en/iachr/mandate/what.asp (2011) (Accessed 27 October 2013)

Phan, Hao Duy. "The ASEAN Inter-Governmental Commission on Human Rights and Beyond." Asia Pacific Bulletin 40 (2009).

Rinshaw, Catherine, "Understanding the New ASEAN Intergovernmental Commission on Human Rights: the Limits and Potential Theory", University of New South Wales Faculty of Law Research Series,
Working Paper 53, (2010): 1-21

The Jakarta Post. 22 July 2009.

The Jakarta Post, 18 March 2013

United Nations, "Report of the Regional Meeting for Asia of the World Conference on Human Rights, United Nations," United Nations, http://www.unhchr.ch/Huridocda/Huridoca.nsf/TestFrame/ 9d23b88f115fb827802569030037ed44?Opendocument (Accessed 27 October 2013)

Working Group for an ASEAN Human Rights Mechanism, "ASEAN Four Signs Declaration of Cooperation," Working Group for an ASEAN Human Rights Mechanism, http://www. aseanhrmech.org/ news/asean-four-signs-declaration-of-cooperation.html (Accessed 27 October 2013)

Yessi Olivia, The Development of Regional Human Rights Systems in America and Southeast Asia, Paper presented in the American Studies Association Annual Meeting, 15-18 November 2012, San Juan, Puerto Rico. 